\author{
Jakub Lawicki \\ Katedra Prawa Karnego Międzynarodowego \\ Uniwersytet Łódzki \\ j.lawicki@onet.pl
}

\title{
Mowa nienawiści \\ — problem odpowiedzialności karnej
}

\section{Zagadnienia wstępne}

Tematyka mowy nienawiści pozostaje jednym z najbardziej problematycznych obszarów w zakresie relacji pomiędzy wolnością słowa a potrzebą ochrony godności osób należących do dyskryminowanych mniejszości i grup społecznych (Wyrok Sądu Okręgowego w Białymstoku z dnia 19 września 2013 r., VIII Ka 422/13).

Incydenty takie, jak: wyzywanie palestyńskiego studenta łódzkiej filmówki w jednym ze sklepów w centrum Łodzi utrwalone za pomocą telefonu komórkowego i umieszczone przez tegoż Palestyńczyka na portalu społecznościowym; spalenie kukły Żyda we Wrocławiu, organizacja marszu w Dzień Niepodległości pod hasłem „Polska dla Polaków. Polacy dla Polski”; przygotowanie plakatu przypominającego grafikę z czasów nazistowskich Niemiec z podpisem „Marsz Patriotów. 11 listopada 2015. Precz z islamem”; zakłócanie w Białymstoku Marszu Jedności przeciwko faszyzmowi krzykami „Nie przepraszam za Jedwabne”, „Polska cała tylko biała”, „Nasza święta rzecz, Żydzi z Polski precz”; noszenie koszulek z sierpem i młotem czy Che Guevarą; malowanie swastyk; umieszczanie na forum 
internetowym wpisów, które nazywały pewnego biznesmena „żydowskim ścierwem” i „typowym Grubym Żydem z wielką głową”; obecność blogera i pisarza Michała Witkowskiego na Fashion Week Poland w czapce z symbolem „SS”; obraźliwe okrzyki wznoszone przez kibiców Lecha Poznań podczas meczu z Widzewem Łódź „waszym domem Auschwitz jest, cała Polska o tym wie, że czerwona armia ta cała pójdzie do pieca!”, „gdzie macie flagę, hej Żydzi”, „do gazu RTS”; rozlepianie przez działaczy ONR plakatów sławiących Eligiusza Niewiadomskiego, fanatycznego nacjonalistę, który w 1922 roku zamordował prezydenta RP Gabriela Narutowicza „Dla was morderca - dla nas bohater”; wygłaszanie podczas manifestacji NOP i Stowarzyszenia Nacjonalistycznego Zadruga przemówień o charakterze rasistowskim, odwołujących się do idei czystości rasy; prezentowanie flagi z symbolem swastyki, transparentów o treści „Europa dla białych, Afryka dla HIV” oraz wznoszenie okrzyków o treści „Biała siła”, „Każdy inny, wszyscy biali”, „Europa dla białych, Afryka dla HIV" - to jedynie wybrane przykłady ukazujące skalę problemu mowy nienawiści, rodzące pytanie o granice wolności słowa oraz bezkarność autorów takich „wypowiedzi”"

Agresja zawarta w powyższych określeniach nakazuje wątpić w poprawność prowadzonego „dyskursu”. Większość z powyższych sformułowań mieści się w pojęciu, które określa się jako „mowa nienawiści”. Na kanwie tego zagadnienia powstają pytania, czym jest mowa nienawiści i co jest powodem problemów w pociągnięciu jej sprawców do odpowiedzialności karnej.

\section{Definicja}

Zagadnienie mowy nienawiści wywodzi się z badań zapoczątkowanych przez socjologię. Niemniej uznać trzeba, iż obecnie mowa nienawiści stała się pojęciem interdyscyplinarnym i podlega analizie dokonywanej nie tylko przez socjologów, ale również językoznawców, dziennikarzy, politologów, psychologów i prawników. Mowa nienawiści należy jednak do tej grupy zagadnień naukowych, które nie doczekały się wyczerpującej analizy w polskiej literaturze przedmiotu.

Z punktu widzenia nauk prawnych, mowa nienawiści jest przedmiotem rozważań pod kątem odpowiedzialności karnej lub cywilnej. Najważniejszą gałęzią prawa traktującą o mowie nienawiści jest niewątpliwie prawo karne, albowiem to ono określa czyny zabronione i stanowi o dolegliwościach stosowanych w drodze przymusu państwowego w stosunku do sprawców przestępstw. Mimo iż mowa

1 Należy jednak zaznaczyć, że nie wszyscy autorzy powyższych „wypowiedzi” uniknęli odpowiedzialności karnej. 
nienawiści nie jest terminem języka prawnego, tj. nie występuje expressis verbis w przepisach prawa, coraz częściej pojawia się w języku prawniczym, czyli języku używanym przez podmioty stanowiące i stosujące przepisy prawne.

Problematyka mowy nienawiści w prawie karnym wynika przede wszystkim $\mathrm{z}$ braku definicji tego pojęcia, tak legalnej, jak i wypracowanej przez naukę lub orzecznictwo, jak również braku zgody co do zakresu przesłanek dyskryminujących.

Zgodnie z dominującą definicją zaproponowaną w Rekomendacji Komitetu Ministrów Rady Europy: mową nienawiści jest każda wypowiedź, która rozpowszechnia, podżega, propaguje lub usprawiedliwia nienawiść rasową, ksenofobię, antysemityzm lub inne formy nienawiści oparte na nietolerancji, włączając $\mathrm{w}$ to: nietolerancję wyrażoną $\mathrm{w}$ formie agresywnego nacjonalizmu, etnocentryzmu, dyskryminacji lub wrogości wobec mniejszości, migrantów lub imigrantów (Rekomendacja Komitetu Ministrów Rady Europy nr [97] 20 z dnia 30 października 1997 r.). Wypada jednak zauważyć, że nie jest to jedna powszechnie aprobowana definicja. Różnice w zdefiniowaniu powyższego pojęcia wynikają min. z różnych granic wolności wypowiedzi w reżimach prawnych poszczególnych państw² ${ }^{2}$.

W Polsce dość dobrze znana jest definicja mowy nienawiści zaproponowana przez Sergiusza Kowalskiego i Magdalenę Tulli (Kowalski, Tulli 2003: 21-23). Według tych autorów, mowa nienawiści to: „każda wypowiedź lżąca, wyszydzająca i poniżająca jednostki lub grupy”. Precyzując, autorzy dodają, że mowa nienawiści jest adresowana do zbiorowości, a nie jednostek. Atak na jednostkę jest atakiem na członka grupy. Ponadto mowa nienawiści ogranicza się do szczególnych zbiorowości. Są to grupy naturalne, określone biologicznie (przynależność etniczna, kolor skóry, płeć, kalectwo, preferencja seksualna) albo społecznie (religia, język, obywatelstwo, miejsce zamieszkania). O ile cechy biologiczne są niezmienne, tak społeczne mogą być z większymi lub mniejszymi trudnościami zmieniane.

W orzecznictwie sądów powszechnych pojawiają się próby samodzielnego określenia pojęcia mowy nienawiści. Mniej lub bardziej dokładne definicje stanowią ważny impuls do prac nad tymże zagadnieniem. Spośród poglądów wyrażonych przez judykaturę warto zwrócić uwagę na definicję zaproponowaną przez Sąd Apelacyjny w Szczecinie. Zgodnie z nią mowa nienawiści: „(...) zmierza do utrwalenia negatywnego i nieprawdziwego wizerunku osób homoseksualnych

2 Różnice wynikają w szczególności z odrębności występujących z systemach prawnych civil law (system prawa kontynentalnego, do którego należy m.in. Polska), a common law (system prawa anglosaskiego, do którego należą m.in. Stany Zjednoczone Ameryki). Zob. Morawski 2006: 77-78, 80-83. Wypada zauważyć, że 1. poprawka do Konstytucji Stanów Zjednoczonych gwarantuje niezwykle szerokie granice wolności słowa. Wypowiedzi bezkarne na terytorium Stanów Zjednoczonych w większości wypadków będą karalne w Polsce, zaś wypowiedzi karalne w Polsce, będą prawnie irrelewantne w Stanach Zjednoczonych. Na temat wolności słowa i wypowiedzi symbolicznych zob. Machaj 2011. 
w opinii publicznej, a osoby, które atakują innych z powodu tych właśnie cech, dowodzą, że same czerpią zadowolenie z zadanego bólu, przy czym dodatkowo są przekonane o swojej wyższości i dominacji”. W ocenie sądu termin ten jest blisko powiązany z pojęciem homofobii (Wyrok Sądu Apelacyjnego w Szczecinie z dnia 4 lutego 2010 r., I ACa 691/09).

Kontrowersje oraz brak zgody co do zakresu mowy nienawiści powodują, że polskie sądy unikają nazywania konkretnych zachowań podejrzanych (oskarżonych) mową nienawiści. Godzi się zauważyć, że pojęcia mowy nienawiści unikają również komentatorzy poszczególnych przepisów kodeksu karnego.

\section{Prawo karne}

Z punktu widzenia nauki prawa karnego konieczne jest określenie katalogu czynów zabronionych, które mogą stanowić podstawy odpowiedzialności za mowę nienawiści.

Obecnie w literaturze przedmiotu zasadnie wskazuje się, że mowa nienawiści objęta jest przez art. 119, 256 i 257 ustawy z dnia 6 czerwca 1997 r. [kodeks karny] (Dz.U. 1997 Nr 88, poz. 553) oraz art. 55 ustawy z dnia 18 grudnia 1998 r. o Instytucie Pamięci Narodowej - Komisji Ścigania Zbrodni przeciwko Narodowi Polskiemu (Tekst jedn. Dz.U. 2014, poz. 1075)3․ Z punktu widzenia prawa karnego międzynarodowego uznanie za mowę nienawiści zbrodni $z$ art. $118 \mathrm{a} \S 3$ pkt $2^{4}$ również nie jest wykluczone.

Publiczne nawoływanie lub pochwalanie przestępstwa $\mathrm{z}$ art. 119 k.k. jest karalne na mocy art. 126a k.k., natomiast publiczne nawoływanie lub pochwalanie pozostałych przestępstw kryminalizowane jest na mocy art. $255 \mathrm{k} . \mathrm{k}$.

Należy zauważyć, że nawet jeżeli nie jest możliwe uznanie konkretnej wypowiedzi za wypełniającą znamiona art. 55 ustawy o IPN oraz art. 119, 256 i 257 k.k., możliwe jest jeszcze przypisanie odpowiedzialności na gruncie przepisów ogólnych: art. 190, 212, 216 k.k. ${ }^{5}$

3 Wydaje się, że granice mowy nienawiści nie obejmują swoim zakresem art. 196 k.k. penalizującego obrazę uczuć religijnych innych osób, znieważając publicznie przedmiot czci religijnej lub miejsce przeznaczone do publicznego wykonywania obrzędów religijnych. Taki też zakres przepisów zdaje się przyjmować M. Woiński, zob. Woiński 2014: rozdział 3.

4 Szczegółowa analiza przepisów prawa karnego międzynarodowego przekraczałaby ramy niniejszego opracowania, dlatego w dalszej części omówione zostaną jedynie regulacje odnoszące się do polskiego prawa karnego.

5 Problematyka tych przepisów zostanie przedstawiona w niniejszym opracowaniu jedynie informacyjnie. 
Art. 119 został umiejscowiony w rozdziale XVI kodeksu karnego o przestępstwach przeciwko pokojowi, ludzkości oraz przestępstwach wojennych. Przewiduje on odpowiedzialność karną osoby, która stosuje przemoc lub groźbę bezprawną wobec grupy osób lub poszczególnej osoby z powodu jej przynależności narodowej, etnicznej, rasowej, politycznej, wyznaniowej lub z powodu jej bezwyznaniowości. Zachowanie sprzeczne z normą zagrożone jest karą pozbawienia wolności od 3 miesięcy do lat 5 . Uchylony w 2010 roku $\$ 2$ tego przepisu przewidywał, że karze pozbawienia wolności od 3 miesięcy do lat 5 podlega również osoba, która publicznie nawołuje do popełnienia przestępstwa określonego $\mathrm{w} \$ 1^{6}$. Mową nienawiści nie będzie ten zakres przepisu, który kryminalizuje odpowiedzialność za stosowanie przemocy. Ta część może być rozpatrywana jako przestępstwo z nienawiści (ang. hate crime). Kolejną grupę przepisów dotyczących mowy nienawiści stanowią art. 256 i 257 k.k. Oba znajdują się w rozdziale XXXII kodeksu karnego o przestępstwach przeciwko porządkowi publicznemu.

Art. $256 \$ 1$ k.k. zawiera dwa typy rodzajowe czynów zabronionych. Po pierwsze zakazuje publicznego propagowania faszystowskiego lub innego totalitarnego ustroju państwa, po drugie - nawoływania do nienawiści na tle różnic narodowościowych, etnicznych, rasowych, wyznaniowych albo ze względu na bezwyznaniowość pod groźbą wymierzenia grzywny. Oba czyny objęte są karą ograniczenia wolności albo pozbawienia wolności do lat 2.

Ta sama kara grozi osobie, która w celu rozpowszechniania produkuje, utrwala lub sprowadza, nabywa, przechowuje, posiada, prezentuje, przewozi lub przesyła druk, nagranie lub inny przedmiot, zawierające treść określoną $\mathrm{w} \$ 1^{7}$ (art. $256 \$ 2$ k.k.). W przypadku skazania za to przestępstwo, sąd zobligowany jest do orzeczenia przepadku tych przedmiotów, nawet jeżeli nie stanowiły one w chwili popełnienia czynu własności sprawcy (art. $256 \$ 4$ k.k.).

Jednocześnie jednak ustawodawca zastrzegł, że nie popełnia przestępstwa $\mathrm{z}$ art. $256 \$ 2$ k.k. osoba, która dopuściła się go w ramach działalności artystycznej, edukacyjnej, kolekcjonerskiej lub naukowej (art. $256 \$ 3$ k.k.).

Drugim typem rodzajowym jest art. 257 k.k. Sankcjonuje on publiczne znieważanie grupy ludności albo poszczególnej osoby z powodu przynależności narodowej, etnicznej, rasowej, wyznaniowej albo z powodu jej bezwyznaniowości lub

$6 \$ 2$ uchylony przez ustawę z dnia 20 maja 2010 r. o zmianie ustawy — Kodeks karny, ustawy o Policji, ustawy - Przepisy wprowadzające Kodeks karny oraz ustawy - Kodeks postępowania karnego, Dz.U. z 2010 Nr 98, poz. 626. Obecnie zakres tego unormowania został włączony do dodanego art. 126a k.k.

7 Dalsza część przepisu „albo będące nośnikiem symboliki faszystowskiej, komunistycznej lub innej totalitarnej” została uznana za niezgodną z art. 42 ust. 1 w zw. z art. 54 ust. 1 i art. 2 Konstytucji RP. Zob. Wyrok Trybunału Konstytucyjnego z dnia 19 lipca 2011 r., K 11/10, OTK-A 2011 Nr 6, poz. 60. 
z takich powodów narusza nietykalność cielesną innej osoby. Karą możliwą do wymierzenia jest kara pozbawienia wolności do lat 3 .

Ostatnim, a jednocześnie pozakodeksowym przepisem jest art. 55 ustawy o IPN. Przepis zakazuje publicznego i wbrew faktom zaprzeczania zbrodniom nazistowskim, komunistycznym oraz innym przestępstwom stanowiącym zbrodnie przeciwko pokojowi, ludzkości lub zbrodnie wojenne popełnione na osobach narodowości polskiej lub obywatelach polskich innych narodowości w okresie od dnia 1 września 1939 roku do dnia 31 lipca 1990 roku. Karą grożącą za postępowanie wbrew treści powyższej normy jest grzywna lub kara pozbawienia wolności do lat 3. Zapadły wyrok jest obligatoryjnie podawany do publicznej wiadomości.

Z powodu nieprecyzyjności zapisów przestępstw mowy nienawiści ${ }^{8}$ nie zawsze istnieje możliwość przypisania odpowiedzialności karnej konkretnie z przepisu przewidującego surowszą sankcję. Niemniej jednak w części szczególnej kodeksu karnego znajdują się również przepisy ogólne, które mogą stanowić podstawę odpowiedzialności za przekroczenie granic wolności słowa. W pierwszej kolejności wskazać trzeba na rozdział XXIII kodeksu karnego dotyczący przestępstw przeciwko wolności. W art. 190 kryminalizuje się grożenie innej osobie popełnieniem przestępstwa na jej szkodę lub szkodę osoby dla niej najbliższej, o ile groźba wzbudza w zagrożonym uzasadnioną obawę, że będzie spełniona. Przestępstwo to ścigane jest na wniosek pokrzywdzonego.

Następne dwa czyny znajdują się w rozdziale XXVII o przestępstwach przeciwko czci i nietykalności cielesnej. W art. $212 \$ 1$ k.k. ustawodawca penalizuje zniesławienie. Karze grzywny albo ograniczenia wolności podlega ten, kto pomawia inną osobę, grupę osób, instytucję, osobę prawną lub jednostkę organizacyjną niemającą osobowości prawnej o takie postępowanie lub właściwości, które mogą poniżyć ją w opinii publicznej lub narazić na utratę zaufania potrzebnego dla danego stanowiska, zawodu lub rodzaju działalności. Dodatkowo karze pozbawienia wolności do roku może podlegać sprawca, jeżeli dopuszcza się on tego czynu za pomocą środków masowego komunikowania. Czyn, o którym mowa, ścigany jest $z$ oskarżenia prywatnego, natomiast $\mathrm{w}$ razie skazania, sąd może orzec nawiązkę na rzecz pokrzywdzonego, Polskiego Czerwonego Krzyża albo na inny cel społeczny wskazany przez pokrzywdzonego. Na wniosek pokrzywdzonego sąd orzeka podanie wyroku skazującego do publicznej wiadomości.

Ustawodawca uznał jednak, że przestępstwo zniesławienia popełnionego normalnie, tj. bez pomocy środków masowego komunikowania, nie zachodzi, jeżeli

8 Ten zwrot uważam za najwłaściwszy dla określenia katalogu przestępstw regulujących problematykę mowy nienawiści w kodeksie karnym. Przyłączam się zatem do stanowisk wyrażonych w literaturze przez M. Płatek oraz M. Woińskiego. Zob. Płatek 2010: 81, Woiński 2010: 32. 
zniesławiający uczynił zarzut niepublicznie i jest on prawdziwy. Ponadto decyzją Parlamentu nie popełnia przestępstwa zniesławienia bez względu na postać osoba, która publicznie podnosi lub rozgłasza prawdziwy zarzut dotyczący postępowania osoby pełniącej funkcję publiczną lub taki, który służy obronie społecznie uzasadnionego interesu. Niemniej, gdy zniesławienie odnosi się do życia prywatnego lub rodzinnego zniesławionego, dowód prawdy może być przeprowadzony tylko wtedy, gdy ów zarzut ma zapobiec niebezpieczeństwu dla życia lub zdrowia człowieka albo demoralizacji małoletniego. Zastrzeżono przy tym, że nawet wyłączenie przestępności zachowania zniesławiającego z powyższych przyczyn nie powoduje wyłączenia odpowiedzialności takiej osoby za zniewagę ze względu na formę podniesienia lub rozgłoszenia zarzutu.

Art. 216 k.k. typizuje przestępstwo znieważenia. Osoba, która znieważa inną osobę w jej obecności albo pod jej nieobecność, lecz publicznie lub w zamiarze, aby zniewaga do osoby tej dotarła, podlega grzywnie albo karze ograniczenia wolności. Dodatkowo karze pozbawienia wolności do roku może podlegać sprawca, jeżeli dopuszcza się on tego czynu za pomocą środków masowego komunikowania. Czyn, o którym mowa, ścigany jest $\mathrm{z}$ oskarżenia prywatnego, natomiast $\mathrm{w}$ razie skazania, ale wyłącznie za znieważenie popełnione za pomocą środków masowego komunikowania, sąd może orzec nawiązkę na rzecz pokrzywdzonego, Polskiego Czerwonego Krzyża albo na inny cel społeczny wskazany przez pokrzywdzonego. Sąd posiada możliwość odstąpienia od wymierzenia oskarżonemu kary, w sytuacji gdy zniewagę wywołało wyzywające zachowanie się pokrzywdzonego, albo jeżeli pokrzywdzony odpowiedział naruszeniem nietykalności cielesnej lub zniewagą wzajemną.

\section{Problematyka karania za mowę nienawiści}

Problem ukarania konkretnego sprawcy za określone zachowanie będące mową nienawiści wynika z niejasności znamion typów rodzajowych z art. 119, 256 i 257 k.k. i art. 55 ustawy o IPN oraz problemów interpretacyjnych, jakie przestępstwa te wywołują w doktrynie prawa karnego. Należy zatem szczegółowo wyjaśnić te zagadnienia, aby ukazać, co stanowi rzeczywisty problem $\mathrm{w}$ pracy prokuratorów i sądów orzekających w sprawach przestępstw mowy nienawiści.

Główny problem dotyczący triady przestępstw z kodeksu karnego sprowadza się do pytania o indywidualny przedmiot ochrony przepisu, co wiąże się z odpowiedzią na kolejne pytanie, czy w postępowaniach dotyczących mowy nienawiści mogą występować pokrzywdzeni, czy też są to tzw. przestępstwa bez ofiar. 
W związku z art. 256 i 257 k.k. rodzi się pytanie o znaczenie „publicznego” działania sprawcy. W doktrynie i orzecznictwie brak jest zgody, czy znamię to oznacza, że zachowanie sprawcze dotarło do większej liczby osób (ważny jest skutek), czy wystarczy, aby wypowiedź mogła dotrzeć do większej liczby osób (skutek nie jest ważny) (Flemming 1999: 18-21). Zagadnienie przybrało na sile w związku z przestępstwem obrazy uczuć religijnych (art. 196 k.k.) i pytaniem, czy zachowanie sprawcy skierowane do określonej grupy słuchaczy, którzy zakupili bilet na zamknięty koncert realizuje znamię publiczności. Problem ten pozostanie aktualny w przypadku nawoływania do nienawiści na zamkniętych spotkaniach, koncertach grup muzycznych, które w treści swoich piosenek propagują faszystowski lub inny totalitarny ustrój państwa, albo nawołują do nienawiści na tle różnic narodowościowych, etnicznych, rasowych, wyznaniowych albo ze względu na bezwyznaniowość.

Brak wskazówek ustawodawcy, czy mimo różnic w zakresie strony podmiotowej pojęcia „nawoływania” z art. $256 \$ 1$ k.k. i „podżegania” użytego w art. $18 \$ 2$ k.k. należy interpretować, jako synonimiczne, jednakowo (Kalitowski 2010: 1117; Mozgawa 2015).

Różnice pomiędzy kodeksem karnym z 1969 roku i kodeksem karnym z 1997 roku zrodziły pytanie o znaczenie "propagowania”, albowiem odpowiednik obecnego art. $256 \$ 1$ k.k. art. $270 \$ 2$ d.k.k. kryminalizował "pochwalanie” (Uchwała Sądu Najwyższego z dnia 28 marca 2002 r., I KZP 5/02, OSNKW 2002, Nr 5-6, poz. 32). Jeżeli bowiem przyjąć, że są to dwa różne i autonomiczne pojęcia, na co wskazuje wykładnia językowa, konieczne staje się ustalenie, czy propagowanie musi być połączone z pochwalaniem.

Również użyte w art. $256 \$ 1$ k.k. słowo „propaguje” wywołuje liczne spory, pozostające bez jednoznacznej odpowiedzi. Nie wiadomo, czy autor wypowiedzi propagujących musi zgadzać się z głoszonymi przez siebie poglądami. Brak wyraźnego stanowiska, czy „propagowanie” faszystowskiego lub innego totalitarnego ustroju państwa oznacza prezentowanie symboli danego ustroju (np. namalowanie swastyki), przedstawienie jakiejś części ustroju (np. antysemityzmu), głoszenie haseł utożsamianych $\mathrm{z}$ danym ustrojem, czy chodzi o propagowanie całego ustroju (Kalitowski 2010: 1119). Odnośnie do ustroju, który propagować ma sprawca - nie jest wiadomym, czy chodzi o ustrój, który istniał lub też istnieje obecnie na świecie, czy ustawodawca miał na myśli każdy ustrój, również ten nigdy niewprowadzony w żadnym z państw i występujący jedynie jako założenie teoretyczne (np. ustrój platoński) (Flemming 1999: 66).

Druga odmiana przestępstwa $\mathrm{z}$ art. $256 ₫ 1 \mathrm{k} . \mathrm{k}$. także powoduje problemy interpretacyjne. W literaturze i orzecznictwie brak jednolitości do znaczenia pojęć 
„nawoływanie” $\mathrm{i}$ „nienawiść”. Również znamię „na tle różnic” nastręcza problemów w wykładni (Woiński 2014: 126). Nie wiadomo bowiem, pomiędzy kim mają występować różnice narodowościowe, etniczne, rasowe, wyznaniowe albo ze względu na bezwyznaniowość. Czy autorzy przepisu mieli na myśli różnice pomiędzy nadawcą a grupą, do nienawidzenia której nawoływany jest odbiorca, czy też różnice te mają zachodzić pomiędzy odbiorcą a wskazanymi grupami?

Problem odpowiedzialności karnej z art. $256 \$ 1$ k.k. polega również na braku jednolitości nauki prawa karnego w zakresie strony podmiotowej. Część doktryny postuluje przyjęcie, że czyn ten można popełnić umyślnie z zamiarem bezpośrednim kierunkowym (dolus directus coloratus), na co wskazują znamiona "propaguje”, „nawołuje”, które mają przesądzać o szczególnym, intencjonalnym zamiarze sprawcy (Herzog 2015: 1639). Inni natomiast ograniczają stronę podmiotową do umyślności wyłącznie z zamiarem bezpośrednim (Kalitowski 2010: 1120).

Wątpliwości, które istniały do momentu stwierdzenia przez Trybunał Konstytucyjny niekonstytucyjności w odpowiednim zakresie art. $256 \$ 2$ k.k., to pytanie o relację $₫ 1$ do $₫ 2$. Pierwszy stanowi bowiem o faszystowskim lub innym totalitarnym ustroju państwa, zaś $\$ 2$ dotyczył faszystowskiego, komunistycznego lub innego totalitarnego. Co więcej, uchylony zapis korespondował z treścią art. 13 Konstytucji RP, który zakazuje istnienia partii politycznych i innych organizacji odwołujących się w swoich programach do totalitarnych metod i praktyk działania nazizmu, faszyzmu i komunizmu, których program lub działalność zakłada lub dopuszcza nienawiść rasową i narodowościową, stosowanie przemocy w celu zdobycia władzy lub wpływu na politykę państwa, albo przewiduje utajnienie struktur lub członkostwa.

Problemy wywołuje również druga jednostka redakcyjna tego przepisu. Trudność polega na interpretacji znamienia „posiada”. Prima facie mogłoby się wydawać, że powinno być rozumiane tak samo jak „posiadanie” na gruncie kodeksu cywilnego. Tak jednak nie jest. Posiadanie w prawie karnym jest terminem szerszym niż to prezentowane na gruncie kodeksu cywilnego. Problem z wykładnią tego znamienia spowodowany jest licznym, sprzecznym ze sobą orzecznictwem dotyczącym posiadania środków odurzających (Zontek 2010: 43-57).

Ponadto doktryna prawa karnego nie potrafi odpowiedzieć na pytanie o różny zakres czynności sprawczych art. $256 \$ 2$ k.k. i art. $202 \$ 3$ k.k. Pierwszy penalizuje produkowanie, utrwalanie lub sprowadzanie, nabywanie, przechowywanie, posiadanie, prezentowanie, przewożenie lub przesyłanie, drugi natomiast produkowanie, utrwalanie lub sprowadzanie, przechowywanie lub posiadanie albo rozpowszechnianie lub prezentowanie. Pierwszy zatem bogatszy jest o nabywanie, prezentowanie, przewożenie i przesyłanie, drugi zaś o rozpowszechnianie i prezentowanie. 
Dotychczas nie rozwiązano również w literaturze i orzecznictwie problemu, jaki wynika $\mathrm{z}$ rozwoju technologii informatycznych, czyli prawnokarnego zagadnienia publikowania linków (odnośników) do zakazanych przez art. $256 \$ 2$ k.k. materiałów. Pozostaje pytanie, czy wykładnia znamienia „przesyła” obejmuje również dokonywanie czynności sprawczych za pomocą internetu, np. poczty elektronicznej (Woiński 2014: 145).

Nie została ponadto rozstrzygnięta kwestia przedmiotu czynności wykonawczej z $\$ 2$. O ile tradycyjne rozumienie druku, nagrania jest możliwe do odkodowania, o tyle nie jest jasne, czy inny przedmiot może stanowić np. drogi serwer (Woiński 2014: 146). Odpowiedź na to pytanie jest istotna z punktu widzenia $₫ 4$, czyli obligatoryjnego przepadku przedmiotów, chociażby nie stanowiły one własności sprawcy. Przepadek naszywki czy płyty CD nie będzie tak dotkliwy jak przepadek bardzo drogiego urządzenia elektronicznego.

Regulacja art. $256 \$ 3$ k.k., czyli kontratypu wprowadza dysharmonię w stosunku do art. 196 k.k., czyli przestępstwa obrazy uczuć religijnych. Przepis art. 196 k.k. nie posiada bowiem postanowień, które pozwalałyby na wyłączenie odpowiedzialności karnej. Problem ten stał się aktualny w związku z koncertami grup metalowych, które w ramach przedstawienia dokonują znieważenia przedmiotu czci religijnej, co może obrażać uczucia religijne.

Wskazany w przepisie art. $256 \S 4$ k.k. obligatoryjny przepadek materiałów $\mathrm{z} \$ 2$ jest kontrowersyjnym środkiem karnym. Słusznie zwraca się uwagę, iż jest to podwójny wyjątek od zasady orzekania przepadku przedmiotów - zasady fakultatywności orzekania przepadku i zasady nieorzekania przepadku w stosunku do przedmiotów niebędących własnością sprawcy (Woiński 2014: 155). Trzeba też z przykrością zauważyć, że ustawodawca de facto uznaje, iż materiały propagujące faszystowski lub inny totalitarny ustrój albo nawołujące do nienawiści są groźniejsze niż środki masowej zagłady i środki wybuchowe, materiały radioaktywne, których przepadek jest... fakultatywny (Woiński 2014: 155). Wyrok Trybunału Konstytucyjnego z dnia 24 listopada 2015 roku spowoduje jeszcze większe problemy, albowiem w stosunku do art. 70 ust. 1 ustawy z dnia 29 lipca 2005 r. o przeciwdziałaniu narkomanii (Dz.U. z 2012 r. poz. 124 oraz z 2015 r. poz. 28 i 875) w zakresie, w jakim dopuszcza orzeczenie przepadku przedmiotu służącego do popełnienia któregoś $\mathrm{z}$ wymienionych $\mathrm{w}$ tym przepisie przestępstw, niebędącego własnością sprawcy, jeżeli właściciel lub inna osoba uprawniona, mimo zachowania ostrożności wymaganej w danych okolicznościach, nie przewidywała i nie mogła przewidzieć, że może on służyć do popełnienia któregoś z tych przestępstw, jest niezgodny z art. 42 ust. 1 w zw. $z$ art. 2 oraz z art. 64 ust. 1 i 3 w zw. z art. 31 ust. 3 
Konstytucji RP9. Stawia to pod dużym znakiem zapytania konstytucyjność art. 256 $\$ 4$ k.k., którego zgodność z ustawą zasadniczą z punktu widzenia zasady proporcjonalności była przedmiotem analiz prawniczych (Woiński 2014: 156).

Odnosząc się do problemów interpretacyjnych drugiego przepisu, tj. art. 257 k.k., należy wskazać, że wątpliwości w zasadzie wiążą się ze znamieniem czasownikowym „znieważa” (Flemming, Kutzmann 1999: 21-29). Tak samo, jak przypadku art. 216 k.k., pojęciu temu zarzuca się ocenność i dowolność. W sytuacji wypowiedzi znieważających nie wiadomo, czy należy brać pod uwagę konkretną wypowiedź znieważającą, czy całość wypowiedzi, w tym jej kontekst, czy tło użytego zwrotu znieważającego.

Nie zostało rozstrzygnięte, czy znieważenie np. Żyda z uwagi na to, że jest Żydem, stanowi pokrzywdzenie całej grupy. W takiej sytuacji należałoby odpowiedzieć na pytanie, czy grupa mogłaby być pokrzywdzonym (Woiński 2014: 164). Podobny problem występuje, gdy poddamy analizie osobę, która nie jest członkiem grupy, ale przez sprawcę błędnie jest za taką uznana. Trudno jednoznacznie odpowiedzieć na pytanie, czy osoba taka może przynależeć do grupy, a tym samym występować jako pokrzywdzony.

Posłużenie się przez ustawodawcę znamieniem „z powodu” uprawnia niektórych autorów do twierdzenia, że w przepisie tym nie chodzi wyłącznie o zamiar bezpośredni (dolus directus), ale zamiar bezpośredni znamienny motywem (dolus directus coloratus) (Herzog 2015: 1640; Kalitowski 2010: 1121).

Także w przypadku art. 55 ustawy o IPN zachodzą wątpliwości interpretacyjne. Autorzy analizujący tenże przepis zwracają uwagę na problem ze wskazaniem dobra prawnego chronionego przez ten przepis. Nie jest także wiadome, czy i ewentualnie jaka relacja istnieje pomiędzy art. 55 ustawy o IPN, a art. 133 k.k. penalizującym publiczne znieważenie Narodu lub Rzeczpospolitej Polskiej (Woiński 2014: 192).

Podczas badania znamion przestępstwa pojawia się kwestia tego, jak rozumieć zaprzeczenie zbrodniom. Czy przepis ustanawia karę wyłącznie za negowanie, czy również umniejszanie zbrodni, ich pochwalanie czy usprawiedliwianie? Nie zostało także rozstrzygnięte, czy o zaprzeczaniu możemy mówić w przypadku negacji, czy dopiero kłamstwa na temat danej zbrodni. Brak również wskazówek, czy ustawodawca miał na myśli całkowite negowanie zbrodni, czy również negację elementów zbrodni (np. liczby ofiar).

9 Trybunał Konstytucyjny badał sytuację, w której sąd powszechny skazał sprawcę za przestępstwo przemytu narkotyków. Jednocześnie, działając na podstawie przepisu zakwestionowanego w tym postępowaniu, orzekł przepadek samochodu osobowego stanowiącego własność skarżącego, wykorzystanego do popełnienia przestępstwa objętego wyrokiem. Skarżący nie był jednak oskarżonym w sprawie karnej, a jedynie jego samochód został wykorzystany do działań o charakterze przestępczym. 
Wątpliwości nasuwa też samo słowo „zbrodnie” użyte w art. 55 IPN w liczbie mnogiej. Mając na uwadze orzecznictwo Sądu Najwyższego w zakresie pojedynczego rozumienia zwrotów użytych w przepisach karnych w liczbie mnogiej, można zasadnie argumentować, że karalne jest również zaprzeczanie jednej zbrodni (Uchwała Sądu Najwyższego z dnia 21 listopada 2001 r., I KZP 26/01, OSNKW 2002 Nr 1-2, poz. 4 z glosami aprobującymi: P. Palka, M. Przetak oraz W. Marcinkowskiego, a także glosami krytycznymi: O. Sitarz oraz M. Klubińskiej, Wyrok Sądu Apelacyjnego we Wrocławiu z dnia 21 lutego 2003 r., II AKa 586/02, OSA $2003 \mathrm{Nr} 5$, poz. 45).

Następne znamię „wbrew faktom” również powoduje problemy interpretacyjne. Badacze nie są zgodni, czy chodzi tu o wiedzę powszechną, niewątpliwą, czy może odwołujemy się do świadomości społecznej (Kulesza 2009: 308).

Konsternację wywołuje także odwołanie do art. 1 ust. 1 ustawy. Twórcy ustawy doprowadzili do sytuacji, w której jeden termin - „zbrodnie komunistyczne” został zdefiniowany (art. 2 ust. 1), natomiast „zbrodnie nazistowskie” (dawniej hitlerowskie ${ }^{10}$ ) już nie. Podobny problem definicyjny dotyczy „zbrodni przeciwko ludzkości”, które zostały zdefiniowane (art. 3), a „przestępstwa przeciwko pokojowi” $i$,zbrodnie wojenne” już nie.

Ponadto z punktu widzenia nauki prawa karnego nie jest jasny termin „zbrodnia” (Woiński 2014: 197, Wyrok Sądu Apelacyjnego w Katowicach z dnia 6 października 2011 r., II AKa 373/11, Prok.i Pr.-wkł. 2012, Nr 5, poz. 27). Kodeks karny definiuje pojęcie zbrodni w art. $7 \$ 2$ k.k. Jednak na gruncie ustawy o IPN można zasadnie twierdzić, że pod pojęciem „zbrodnia”, rozumie się również występki ${ }^{11}$, ponieważ termin „zbrodnia” nie został tam zdefiniowany.

Wskazując na dalsze wątpliwości: aktualne pozostaje pytanie o znaczenie „publicznego" działania sprawcy oraz obawa o autorów publikacji naukowych, badających i polemizujących z danymi historycznymi (Janisławski, Konopka 2009: 50-51).

Ostatni problem to strona podmiotowa i pytanie, z jakim zamiarem można popełnić czyn. Czy chodzi o zamiar bezpośredni, bo ustawodawca posługuje się zwrotem „wbrew faktom”, czy również o działanie z zamiarem ewentualnym (Kulesza 2005: 103; Rejman 2006: 3; Przyjemski 2006: 15) ${ }^{12}$.

10 Termin ten występował w ustawie z dnia 6 kwietnia 1984 r. o Głównej Komisji Badania Zbrodni przeciwko Narodowi Polskiemu - Instytucie Pamięci Narodowej (Dz.U. 1984, Nr 21, poz. 98). Jednak również w tej ustawie nie został zdefiniowany.

11 Przestępstwa dzielą się na zbrodnie i występki. Zob. art. 7 k.k.

12 Ramy tekstu nie pozwalają na zaprezentowanie wszystkich zagadnień problematycznych omawianych przepisów. Na te i inne pytania autor tekstu stara się odpowiedzieć w swojej dysertacji doktorskiej. 


\section{Zakończenie}

Ocena regulacji przestępstw mowy nienawiści nie może być jednoznacznie pozytywna, niemniej nie można zgodzić się z postulatami całkowitej depenalizacji albo uchylenia konkretnych przepisów ${ }^{13}$. Za otwartą uważam jednak podnoszoną w literaturze potrzebę uchylenia w art. $256 \$ 3$ k.k. (Woiński: 155, 207). Wydaje się, że właściwszym będzie doprecyzowanie typów rodzajowych tak, aby konkretne znamiona pozwalały na ich bezsporną interpretację. Zasadne jest zatem dokonanie nowelizacji art. 256 k.k. (w szczególności $\$ 4$ ) i art. 257 k.k.

Mimo problemów z przypisaniem odpowiedzialności karnej za przestępstwa mowy nienawiści, należy pozytywnie ocenić działania Prokuratora Generalnego, Andrzeja Seremeta (dalej: Prokurator Generalny, PG), w ich zwalczaniu. Od 2014 roku zwierzchnik prokuratury prowadził intensywne działania w celu ujednolicenia praktyki w zakresie sposobu prowadzenia postępowań karnych o przestępstwa nienawiści, tj. popełnianych na szkodę grupy osób albo poszczególnej osoby z powodu jej przynależności narodowej, etnicznej, rasowej, politycznej, wyznaniowej albo ze względu na jej bezwyznaniowość, niezależnie od kwalifikacji prawnej czynu zabronionego. Do dnia dzisiejszego PG wydał wytyczne w zakresie prowadzenia postępowań o przestępstwa z nienawiści (Wytyczne z dnia 26 lutego 2014 r., PG VII G 021/54/13), wytyczne w sprawie udziału prokuratora w sprawach o przestępstwa prywatnoskargowe (Wytyczne z dnia 29 października 2012 r., PG VII G 021/24/12), metodykę prowadzenia spraw dotyczących przestępstw z nienawiści za pośrednictwem internetu (Pismo Prokuratora Generalnego z dnia 27 października 2014 r. przedstawiające metodykę prowadzenia spraw dotyczących przestępstw z nienawiści za pośrednictwem internetu, PG I A0021/1/14).

Pierwszy dokument stanowi wskazówki dla prokuratorów, jak prowadzić postępowania przygotowawcze. Prokurator Generalny zaleca zwrócenie uwagi na potrzeby dokonania precyzyjnych i miarodajnych ustaleń zamiaru sprawcy w oparciu o materiał dowodowy, w szczególności w oparciu o sposób działania sprawcy, dokonywania czynności z udziałem pokrzywdzonych w sposób zapobiegający wtórnej wiktymizacji, z poszanowaniem ich godności, niezwłocznego uzyskiwania adresu IP komputera, z którego dokonano przestępstwa, oraz zapisów monitoringu publicznego lub prywatnego, kompleksowej analizy faktycznej potrzeby pozyskania opinii biegłego z zakresu językoznawstwa, historii lub innej dziedziny wiedzy,

13 Płatek 2010: 90. Autorka opowiada się za uchyleniem tak art. 256 k.k., jak i art. 257 k.k. i pozostawieniem zachowań objętych dyspozycją obu tych przepisów w sferze odpowiedzialności cywilnoprawnej i administracyjnej. Zob. też Woiński 2014: 155, 156, 207. Autor ten poddaje pod dyskusję propozycję uchylenia art. $256 \$ 2-4$ k.k. 
przypominając, że: „niedopuszczalne jest zasięganie opinii biegłych w zakresie faktów i ocen oczywistych, ogólnie przyjętych oraz prezentowanych w powszechnie dostępnych źródłach" oraz że to nie biegły dokonuje ocen prawnokarnych analizowanych zachowań, wnikliwego uzasadniania decyzji procesowych, w szczególności rozstrzygnięć kończących postępowanie, tak aby były one zrozumiałe dla uczestników postępowania karnego oraz opinii publicznej oraz wskazywały na „świadomość wagi i znaczenia dóbr chronionych prawem” naruszonych czynem zabronionym.

W przedmiocie postępowań prywatnoskargowych, czyli ogólnych przepisów art. 212 i 216 k.k., PG uznał, że podlegli prokuratorzy powinni oceniać, czy istnieje interes społeczny wymagający objęcia ściganiem z urzędu przestępstwa prywatnoskargowego. Dokonując tej analizy, prokuratorzy powinni brać pod uwagę w szczególności:

(...) okoliczności odnoszące się do osoby pokrzywdzonego, w tym zwłaszcza jego zdolności do realizacji uprawnień w zakresie oskarżenia prywatnego, uwzględniając w szczególności nieporadność z uwagi na wiek, chorobę, kalectwo, zależność od sprawcy i szczególnie trudną sytuację życiową; okoliczności odnoszące się do strony podmiotowej (szczególną złośliwość) i przedmiotowej czynu (działanie w miejscu publicznym, poważny rodzaj i rozmiar ujemnych następstw przestępstwa) oraz charakteryzujące sprawcę (jego właściwości i warunki osobiste); konieczność kształtowania świadomości prawnej społeczeństwa i poczucia, że organy państwowe stanowczo reagują na drastyczne przypadki łamania prawa. Okoliczności te nie muszą występować łącznie. (Wytyczne z dnia 29 października 2012 r., PG VII G 021/24/12)

Ostatni dokument, metodyka prowadzenia spraw dotyczących przestępstw z nienawiści za pośrednictwem internetu, stanowi vademecum dla prokuratorów, przedstawiając im czynności i sposoby ich wykonywania odnośnie do skomplikowanej technologii internetowej i materiały, jakie należy zgromadzić w sprawach dotyczących przestępstw z nienawiści.

Wypada zatem uznać, że mimo problematyki stosowania przepisów dotyczących przestępstw mowy nienawiści, szerokie zainteresowanie badawcze zagadnieniem hate speech prowadzi do niezamierzonego celu — zwiększenia wiedzy o tolerancji i zwiększenia wrażliwości na odmienność innych osób.

Na koniec warto zacytować słowa, które winny służyć za podsumowanie: „Nie możemy popełniać błędów z przeszłości. Ludobójstwo nie zaczęło się od zabijania. Na początku zawsze jest słowo-trucizna” (Junczyk-Ziomecka 2010: 18). 


\section{Bibliografia}

Flemming Marian (1999) [w:] Przestępstwa przeciwko porządkowi publicznemu. Rozdział XXXII Kodeksu karnego. Komentarz, M. Flemming, W. Kutzmann, Wydawnictwo C.H. Beck, Warszawa.

Flemming Marian, Kutzmann Witold (1999) [w:] Przestępstwa przeciwko porzadkowi publicznemu. Rozdział XXXII Kodeksu karnego. Komentarz, M. Flemming, W. Kutzmann, Wydawnictwo C.H. Beck, Warszawa.

Herzog Aleksander (2015) [w:] Kodeks karny. Komentarz, R. A. Stefański (red.), Wydawnictwo C.H. Beck, Warszawa.

Janisławski Adam, Konopka Piotr (2009), Zagadnienie penalizacji „kłamstwa oświęcimskiego”, „Palestra”, nr 1-2.

Junczyk-Ziomecka Ewa (2010), List Minister Ewy Junczyk-Ziomeckiej, Sekretarz Stanu $w$ Kancelarii Prezydenta RP Lecha Kaczyńskiego, do organizatorów i uczestników konferencji [w:] R. Wieruszowski, M. Wyrzykowski, A. Bodnar, A. Gliszczyńska-Grabias (red.), Mowa nienawiści a wolność słowa. Aspekty prawne i społeczne, Wolters Kluwer, Warszawa.

Kalitowski Michał (2010) [w:] Kodeks karny. Komentarz, M. Filar (red.), LexisNexis, Warszawa.

Kowalski Sergiusz, Tulli Magdalena (2003), Zamiast procesu. Raport o mowie nienawiści, Wydawnictwo W.A.B., Warszawa.

Kulesza Jerzy A. (2005), Z problematyki strony podmiotowej zbrodni komunistycznej, „Wojskowy Przegląd Prawniczy”, nr 3.

Kulesza Witold (2009), „Kłamstwo o Auschwitz” jako czyn zabroniony w polskim i niemieckim prawie karnym [w:] Ł. Pohl (red.), Aktualne problemy prawa karnego. Ksiega pamiatkowa z okazji jubileuszu 70. Urodzin Profesora Andrzeja J. Szwarca, Wydawnictwo Naukowe UAM, Poznań.

Machaj Łukasz (2011), Wypowiedzi symboliczne w orzecznictwie Sądu Najwyższego USA, Wydawnictwo Uniwersytetu Wrocławskiego, Wrocław.

Morawski Lech (2006), Wstęp do prawoznawstwa, Wydawnictwo Dom Organizatora, Torun.

Mozgawa Marek (2015) [w:] Kodeks karny. Komentarz, M. Mozgawa (red.), Wolters Kluwer, Warszawa.

Płatek Monika (2010), Mowa nienawiści - przesłanki depenalizacji [w:] R. Wieruszowski, M. Wyrzykowski, A. Bodnar, A. Gliszczyńska-Grabias (red.), Mowa nienawiści a wolność słowa. Aspekty prawne i społeczne, Wolters Kluwer, Warszawa. 
Przyjemski Stanisław Maria (2006), W kwestii pojęcia „zbrodni komunistycznej”, zdefiniowanej $w$ art. 2 ust. 1 ustawy $z$ dnia 18 grudnia 1998 r. o Instytucie Pamięci Narodowej - Komisji Ścigania Zbrodni przeciwko Narodowi Polskiemu, „Wojskowy Przegląd Prawniczy”, nr 1.

Rejman Genowefa (2006), Zbrodnie komunistyczne w koncepcji polskiego prawa karnego, „Wojskowy Przegląd Prawniczy”, nr 1.

Woiński Mateusz (2014), Prawnokarne aspekty zwalczania mowy nienawiści, LexisNexis, Warszawa.

Zontek Witold (2010), Jak posiadać, aby nie posiadać? Kilka refleksji nad orzecznictwem sadowym ostatnich lat w sprawach narkotykowych, „Czasopismo Prawa Karnego i Nauk Penalnych", z. 1.

\section{Jakub Lawicki}

\section{Mowa nienawiści — problem odpowiedzialności karnej}

Hate Speech — The Criminal Responsibility Problem

Słowa kluczowe: mowa nienawiści, nawoływanie, propagowanie, nienawiść, znieważenie

Key words: hate speech, inciting, propagation, hate, insult

\section{Streszczenie}

Przedmiotem artykułu jest problematyka odpowiedzialności karnej za mowę nienawiści. W artykule poruszono zagadnienia publicznego propagowania faszystowskiego lub innego totalitarnego ustroju państwa, nawoływania do nienawiści na tle różnic narodowościowych, etnicznych, rasowych, wyznaniowych albo ze względu na bezwyznaniowość, publicznego znieważania grupy ludności lub poszczególnych osób z powodu przynależności narodowej, etnicznej, rasowej, wyznaniowej albo powoduje względu na jej bezwyznaniowość oraz publicznego i wbrew faktom zaprzeczania zbrodniom nazistowskim, komunistycznym oraz innym prze- 
stępstwom stanowiącym zbrodnie przeciwko pokojowi, ludzkości lub zbrodnie wojenne popełnionym na osobach narodowości polskiej lub obywatelach polskich innych narodowości w okresie od dnia 1 września 1939 roku do dnia 31 lipca 1990 roku. Autor przedstawia definicje mowy nienawiści i analizuje znamiona art. 119, 256 i 257 k.k. oraz art. 55 IPN prezentując problemy z ich interpretacją. W konkluzji autor wskazuje na pozytywne działania Prokuratora Generalnego z lat 2010-2016 w sprawie mowy nienawiści.

\begin{abstract}
The subject of the article is the problem of criminal responsibility for hate speech. The article deals with issues of public propagation fascist or other totalitarian political system, inciting to hatred on national, ethnic, racial, political or religious differences or because of irreligiousness, public insult group or individual because of national, ethnic, racial, political or religious differences or because of irreligiousness, unlawful threat towards a group or individual because of national, ethnic, racial, political or religious differences of because of irreligiousness and public and contrary to the facts denying the nazi crimes, the communist crimes and other offences being crimes against peace, crimes against humanity and war crimes committed on people of Polish nationality or Polish citizens of other nationalities between $1^{\text {st }}$ September 1939 until $31^{\text {st }}$ July 1990. Author presents hate speech definitions and analyses elements art. 119, 256 and 257 criminal code and art. 55 Act on the Institute of National Remembrance, presenting problems with its interpretation. In conclusion author points out positive actions of Prosecutor General from years 2010-2016 on hate speech.
\end{abstract}

